\title{
EXPRESSIVITY OF TOCOPHEROL MUTATIONS IN SUNFLOWER
}

\author{
Demurin, Ya.N. ${ }^{*}$, Efimenko, S.G., and Peretyagina, T.M. \\ All-Russia Research Institute of Oil Crops "V.S. Pustovoit" (VNIIMK), Filatova 17, \\ 350038, Krasnodar, Russia
}

Received: October 15, 2006

Accepted: December 05, 2006

\begin{abstract}
SUMMARY
Influences of genetic background, ontogenesis and environment on tocopherol mutations in sunflower were estimated in this study. The content of $\alpha / \beta$ tocopherols varied from $40 / 60$ to $60 / 40 \%$ in seeds of different inbred lines containing the tph 1 gene. The lines containing the tph 2 gene ranged widely in $\alpha / \gamma$ tocopherols, from $0 / 100$ to $80 / 20 \%$. A double mutation showed variability in different inbred lines in $\alpha / \beta / \gamma / \delta$-tocopherol contents from maximum expressivity of $0 / 0 / 60 / 40$ to minimum $40 / 25 / 25 / 10 \%$, due to incomplete expressivity of tph2. Seed maturation from 10 to $38 \mathrm{DAF}$ influenced tocopherol composition in both normal and mutant genotypes by increasing the $\alpha$-tocopherol content. The content varied from 81 to $97 \%$ in a normal genotype, from 33 to $50 \%$ in tph 1 mutation and from 0 to $6 \%$ in tph2 mutation. Tocopherol mutations were shown to express their phenotype in different parts of a plant. All roots, hypocotyls, leaves, pollen and callus from the seeds, hypocotyls and leaves had normal, tph1, tph2 and double mutation tocopherol profiles depending on the genotype. The only exception was the absence of tph 1 expressivity in the green tissue of the leaves. The experiment with day/night temperatures varying during seed development from $20 / 18$ to $30 / 26^{\circ} \mathrm{C}$ showed an increased $\alpha$-tocopherol content from 39 to $48 \%$ in tph1 mutation. Both a normal genotype (about $97 \%$ of $\alpha$-tocopherol) and tph 2 mutation (about $98 \%$ of $\gamma$-tocopherol) were constant in these two temperature regimes. Genetic background was the main factor that influenced the expressivity of tph2 in sunflower.
\end{abstract}

Key words: expressivity, sunflower, tocopherol mutations

\section{INTRODUCTION}

Sunflower tocopherol complex is known to contain mostly the $\alpha$-homologue, about $95 \%$, which has the highest vitamin content and lowest antioxidant properties. Other oil crops mainly possess high percentages of other homologues, especially $\gamma$-tocopherol, making the complex more balanced. It seems to be possible to increase the oil oxidative stability via high level of antioxidant protection achieved

* Corresponding author: e-mail: yakdemurin@yandex.ru 
by breeding for enhanced tocopherol composition in sunflower seeds (Demurin et al., 1996).

Two unlinked non-allelic genes, designated Tph1 and Tph2, controlling tocopherol composition in sunflower seeds were identified for the first time in VNIIMK, Krasnodar, Russia (Demurin, 1993). Recessive alleles of the genes were found as spontaneous mutations using large-scale screening, selfing and the half-seed technique. Original inbred lines with modified tocopherol composition, LG15, LG17 and LG24, have been developed. Tph1 gene controls the ratio of $\alpha$ - and $\beta$-tocopherols, whereas Tph2 gene affects that of $\alpha$ - and $\gamma$-homologues. The tph2 mutation exhibits epistasis over tph 1 through the expression of $\delta$-tocopherol content amounting to about $8 \%$ in the recombinant double recessive homozygote LG24.

Two new inbred lines, T589 with medium $\beta$-tocopherol content and T2100 with high $\gamma$-tocopherol content, have been recently developed in CSIC, Cordoba, Spain (Velasco et al., 2003). The genetic identification by the allelic test showed the new medium $\beta$-tocopherol mutation to be allelic to tph 1 and the new high $\gamma$-tocopherol mutation to be allelic to tph2 (Demurin et al., 2004; Vera-Ruiz et al., 2005). The $\delta$ tocopherol content in the phenotype of a recombinant double mutation achieved in segregants up to $68 \%$ (Velasco et al., 2004).

A linkage test in the $\mathrm{F}_{2}$ and $\mathrm{F}_{3}$ generations showed the tph1 and tph2 mutations to be independently inherited from the Imr gene for imidazolinone resistance (Demurin et al., 2006).

The molecular genetic approach revealed a modifying cryptic recessive mutation, designated $d$, which has no effect in a normal genotype but increases the $\beta$ tocopherol content up to $70 \%$ in tph1tph1 dd homozygotes and to $40 \%$ in tph 1 tph 1 tph2tph2 $d d$ homozygotes. Three methyltransferase mutations, $m$ (tph1), $g$ (tph2) and $d$ were mapped to linkage groups 1, 8 and 4, respectively (Hass et al., 2006; Tang et al., 2006).

The present investigation was undertaken to estimate the effect of different factors on phenotypic variability of tocopherol mutations.

\section{MATERIALS AND METHODS}

Inbred lines from the genetic collection of VNIIMK were involved in this research. VK66 and VK373 were normal lines. The genotypes LG15 and VK571 contained the tph1 gene. The genotypes LG17 and VK175 contained the tph 2 gene. LG24 and VK876 possessed a double tph1, tph2 mutation.

Leaves, hypocotyls and roots were sampled from V6 plants. Five-week calli were obtained at $25^{\circ} \mathrm{C}$ in the dark. Explants were placed in Murashige-Skoog medium with BAP (0.5 mg/l), NAA (2 mg/l), hydrolyzed casein (500 mg/l), mesoinositol (100 mg/l), sucrose (30 g/l), agar ( $8 \mathrm{~g} / \mathrm{l})$, glycine $(2 \mathrm{mg} / \mathrm{l})$, vitamin $\mathrm{B}_{1}(10 \mathrm{mg} /$ 1), vitamin $\mathrm{B}_{6}(1 \mathrm{mg} / \mathrm{l})$ and vitamin $\mathrm{PP}(1 \mathrm{mg} / \mathrm{l})$ with $\mathrm{pH}$ from 5.6 to 5.8 . After drying and crushing, the samples were analyzed for tocopherol composition. 
Seed maturation was effected in two climatic chambers with different day/night temperature regimes, $20 / 18^{\circ} \mathrm{C}$ and $30 / 26^{\circ} \mathrm{C}$ per day/night. Day length was $16 \mathrm{~h}$. Plants were grown in pots filled with the soil.

Tocopherol composition was determined with thin-layer chromatography (TLC) followed by Emmerie-Engel reaction without correction due to different rates of homologue staining (Popov et al., 1991).

\section{RESULTS AND DISCUSSION}

Expressivity of mutations is known to be estimated on the basis of phenotypic variability exhibited under the influence of modifier genes of different genetic backgrounds, plant ontogenesis and environment factors.

Table 1: Expressivity of tocopherol mutations in different genetic backgrounds of inbred lines

\begin{tabular}{|c|c|c|c|c|c|}
\hline \multirow{2}{*}{ Mutation } & \multirow{2}{*}{ Expressivity } & \multicolumn{4}{|c|}{ Tocopherol composition, \% } \\
\hline & & $\alpha$ & $\beta$ & $\gamma$ & $\delta$ \\
\hline \multirow{2}{*}{ tph1 } & $\max$ & 40 & 60 & 0 & 0 \\
\hline & $\min$ & 60 & 40 & 0 & 0 \\
\hline \multirow{2}{*}{ tph2 } & $\max$ & 0 & 0 & 100 & 0 \\
\hline & $\min$ & 80 & 0 & 20 & 0 \\
\hline \multirow{2}{*}{ tph1, tph2 } & $\max$ & 0 & 0 & 60 & 40 \\
\hline & $\min$ & 40 & 25 & 25 & 10 \\
\hline
\end{tabular}

Genetic background of different lines was found to influence markedly the expressivity of tph 2 mutation and double recessive homozygote. The $\gamma$-tocopherol percentage in tph2 varied from the maximum expressivity of $100 \%$ to a minimum level of $20 \%$ (Table 1 ). The double recessive homozygotes showed maximum expressivity in VK876 sub-line with $60 \%$ of $\gamma$ - and $40 \%$ of $\delta$-homologues. The minimum levels of expressivity corresponded to the tocopherol profiles with $40 \%$ of $\alpha$-, $25 \%$ of $\beta$-, $25 \%$ of $\gamma$ - and $10 \%$ of $\delta$-form.

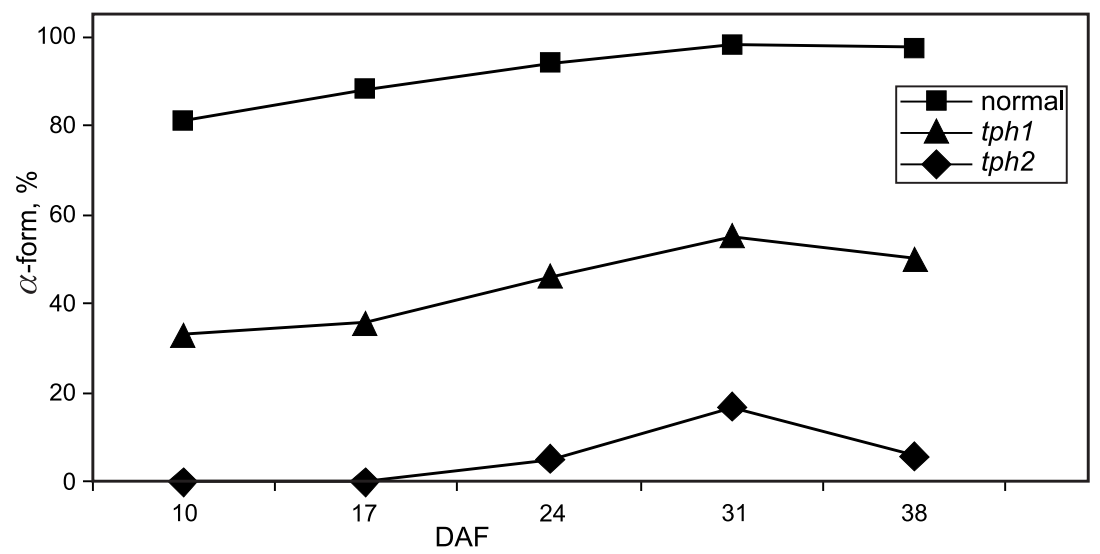

Figure 1: Influence of seed maturation (days after flowering) on $\alpha$-tocopherol content of different genotypes 
The range of variability of the phenotype possessing the tph 1 gene was even lower. The $\beta$-tocopherol percentage varied from 60 to $40 \%$, with corresponding changes of $\alpha$-tocopherol content from 40 to $60 \%$.

Seed maturation from 10 to 38 days after flowering (DAF) influenced tocopherol composition in both normal and mutant genotypes by increasing the $\alpha$-tocopherol content. In the normal genotype VK373, this increase varied from 81 to $97 \%$, in LG 15 with tph 1 from 33 to $50 \%$ and in LG17 with tph2 from 0 to $6 \%$ (Figure 1).

Mutations in tocopherol composition can be detected in different parts of the plant (Table 2). All roots, hypocotyls, leaves, pollen grains and calli from the seeds, hypocotyls and leaves had normal, tph1, tph2 and double mutation tocopherol profiles depending on the genotype. The only exception was the absence of tph 1 expressivity in the green tissue of the leaves in both single and double mutations.

Table 2: Expressivity of tocopherol mutations in different plant parts

\begin{tabular}{lccccc}
\hline \multirow{2}{*}{ Mutation } & \multicolumn{5}{c}{ Plant part } \\
\cline { 3 - 6 } & seed /callus & hypocotyl /callus & leaf /callus & root & pollen \\
wild type & $-/-$ & $-/-$ & $+/+$ & $-/+$ & - \\
tph1 & $+/+$ & $+/+$ & $+/+$ & + & + \\
tph2 & $+/+$ & $+/+$ & $+* /+$ & + & + \\
tph1, tph2 & $+/+$ & & & + \\
\hline
\end{tabular}

* expressivity observed as tph2 phenotype

It was shown for tph1 and tph2 mutations that heterozygotes could be clearly identified after pollen analysis from one head for mean tocopherol content (Table 3 ). That was possible due to monoheterozygotes production of the mixture of heterogeneous pollen grains of two types in 1 normal : 1 mutant ratio. Double heterozygotes produced a mixture of heterogeneous pollen grains of four types in 1 normal : 1 tph 1 : 1 tph2 : 1 tph 1 , tph2 ratio. This is suitable for backcrossing selection in developing of analogues of elite lines.

Table 3: Tocopherol profiles of pollen from a single head of different genotypes

\begin{tabular}{lcccc}
\hline \multirow{2}{*}{ Genotype } & \multicolumn{4}{c}{ Tocopherol composition in pollen, \% } \\
\cline { 2 - 5 } & $\alpha$ & $\beta$ & $\gamma$ & $\delta$ \\
\hline wild type & 85 & 0 & 15 & 0 \\
Tph1tph1 & 70 & 20 & 10 & 0 \\
tph1tph1 & 60 & 40 & 0 & 0 \\
Tph2tph2 & 60 & 0 & 40 & 0 \\
tph2tph2 & 15 & 0 & 85 & 0 \\
Tph1tph1 Tph2tph2 & 40 & 10 & 40 & 10 \\
tph1tph1 tph2tph2 & 0 & 0 & 50 & 50 \\
\hline
\end{tabular}

The experiment with day/night temperature regimes during seed development at $20 / 18$ and $30 / 26^{\circ} \mathrm{C}$ showed the tph 1 mutation to be increased in $\alpha$-tocopherol content from 39 to $48 \%$. Thus, the higher the temperature, the higher $\alpha$-tocopherol and the lower $\beta$-tocopherol percentages. Both the normal genotype (about $97 \%$ of $\alpha$ - 
tocopherol) and the tph2 mutation (about $98 \%$ of $\gamma$-tocopherol) were constant in these two regimes (Figure 2).

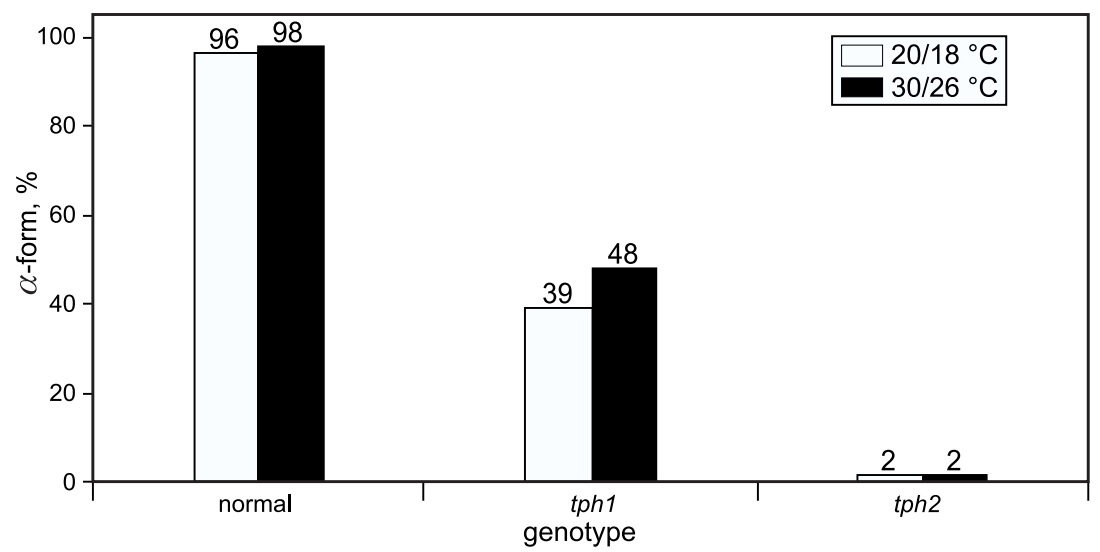

Figure 2: Influence of temperature during seed maturation on $\alpha$-tocopherol content in different genotypes

There are two routes of $\alpha$-tocopherol biosynthesis in plants. The route from $\gamma$ to $\alpha$ - may be the main route and that from $\delta$ - via $\beta$ - to $\alpha$-tocopherol may be a minor one (Furuya et al., 1987). Obviously, different "5-carbon" and "7-carbon" methyltransferases are involved. The tph1 mutation was recently shown to knock out the "5-carbon" type of enzyme: 2-demethylphytylplastoquinol methyltransferase (or MPBQ/MSBQ-MT) and the tph2 mutation to knock out the "7-carbon" type of enzyme: $\gamma$-tocopherol methyltransferase ( $\gamma$-TMT) (Hass et al., 2006; Tang et al., 2006).

Different phenotypes of the mutations, due to the different expressivity, can be explained with the general scheme of proposed genetic blocks in tocopherol biosynthesis where $\alpha$-form is a terminal compound (Figure 3). For example, the higher the tph2 expressivity in the double mutations, the higher the contents of $\gamma$ - and $\delta$-tocopherols. Conversely, the low level of tph 2 expressivity may lead to an additional accumulation of both $\alpha$ - and $\beta$-tocopherol. On the other hand, immature seeds were expected to contain increased percentages of precursors, i.e., $\beta$-, $\gamma$ - and $\delta$-form, and a decreased content of $\alpha$-tocopherol. Finally, the high temperature during seed development cannot change tocopherol profiles in the case of extremely high percentages of the terminal compounds: $\alpha$-tocopherol in normal genotypes or $\gamma$-tocopherol in tph2 mutations.

\section{CONCLUSIONS}

The modifier genes of genetic backgrounds, seed maturation and tissue-specific expression in different parts of a plant, such as root, hypocotyls, leaves, pollen and callus, and temperature during seed maturing were shown to influence the expressivity of tph1 and tph2 tocopherol mutations in sunflower. The main factor was genetic background. 
<smiles>Cc1cc(O)cc(C/C=C\C(C)CCCC(C)C)c1O</smiles>

2-demethylphytylplastoquinol

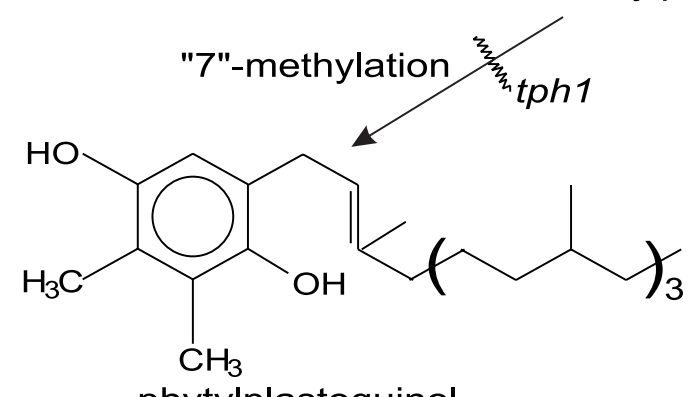

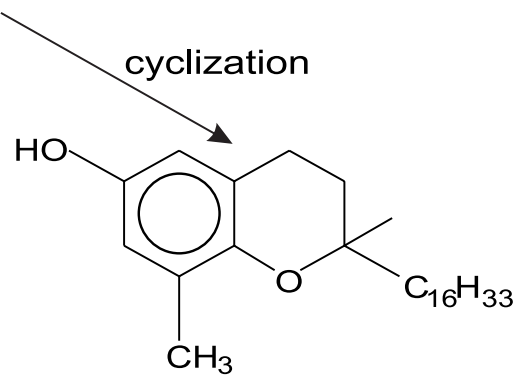

phytylplastoquinol $\delta$-tocopherol

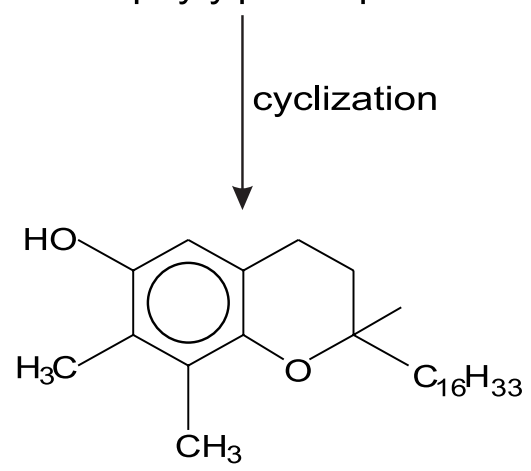

$\gamma$-tocopherol<smiles>Cc1cc(O)c(C)c2c1OC(C)(C(C)(C)C)CC2</smiles>

"5"-methylation

$\beta$-tocopherol

tph 2<smiles>Cc1c(C)c2c(c(C)c1O)CCC(C)(C(C)(C)C)O2</smiles>

$\alpha$-tocopherol

Figure 3: Proposed genetic blocks in tocopherol biosynthesis with tph1 and tph2 mutations in sunflower 


\section{ACKNOWLEDGEMENTS}

This work was supported by grant 06-04-96633 from the Russian Foundation for Basic Research (RFFI).

\section{REFERENCES}

Demurin, Ya.N., 1993. Genetic variability of tocopherol composition in sunflower seeds. Helia 16(18): 59-62.

Demurin, Ya.N., Škorić, D., Karlović, Dj., 1996. Genetic variability of tocopherol composition in sunflower seeds as a basis of breeding for improved oil quality. Plant Breeding 115 : 33-36.

Demurin, Ya.N., Efimenko, S.G., Peretyagina, T.M., 2004. Genetic identification of tocopherol mutations in sunflower. Helia 27(40): 113-116.

Demurin, Ya.N., Borisenko, O.M., Peretyagina, T.M., Perstenyeva, A.A., 2006. Gene linkage test for Imr with $\mathrm{Ol}$, Tph1 and Tph2 mutations in sunflower. Helia 29(44): 41-46.

Furuya, T., Yoshikawa, T., Kimura, T., Kaneko, H., 1987. Production of tocopherols by cell culture of safflower. Phytochemistry 26(10): 2741-2747.

Hass, C.G., Tang, S., Leonard, S., Traber, M.G., Miller, J.F., Knapp, S.J., 2006. Three nonallelic epistatically interacting methyltransferase mutations produce novel tocopherol (vitamin E) profiles in sunflower. Theor. Appl. Genet. 113: 767-782.

Popov, P.S., Aspiotis, E.H., 1991. Biochemical methods for breeding material estimation. Biology, Breeding and Growing of Sunflower, Moscow: pp 77-80.

Tang, S., Hass, C.G., Knapp, S.J., 2006. Ty3/gypsy-like retrotransposon knockout of a 2-methyl6phytyl-1,4-benzoquinone methyltransferase is non-lethal, uncovers a cryptic paralogous mutation, produces novel tocopherol (vitamin E) profiles in sunflower. Theor. Appl. Genet. 113: 783-799.

Velasco. L., Fernandez-Martinez. J.M., 2003. Identification and genetic characterization of new sources of beta- and gamma-tocopherol in sunflower germplasm. Helia 26(38): 17-23.

Velasco, L., Perez-Vich, B., Fernandez-Martinez, J.M., 2004. Development of sunflower germplasm with high delta-tocopherol content. Helia 27(40): 99-106.

Vera-Ruiz, E.M., Perez-Vich, B., Fernandez-Martinez, J.M., Velasco, L., 2005. Comparative genetic study of two sources of beta-tocopherol in sunflower. Helia 28(42): 1-8.

\section{EXPRESIÓN DE GENES DE MUTACIÓN DE TOCOFEROL EN GIRASOL}

\section{RESUMEN}

En este trabajo ha sido estudiada la influencia del fondo genético, ontogénesis y el entorno en mutaciones de tocoferol en girasol. El contenido de $\alpha / \beta$ tocoferol, varía entre $40 / 60$ y $60 / 40 \%$ en la semilla de diferentes líneas consanguíneas (inbred) que contenían el gen tph1. Las líneas con el gen tph2, varían ampliamente en contenido de $\alpha / \gamma$-tocoferol, de 0/100 a 80/20\%. Una mutación doble mostró la variabilidad en el contenido de $\alpha / \beta / \gamma / \delta$-tocoferol en diferentes líneas consanguíneas (inbred) que varía entre la expresión máxima de 0/0/60/ 40 a la expresión mínima de 40/25/25/10\%, lo que es consecuencia de expresividad incompleta del gen tph2. La maduració de semilla de 10 a 38 días después de floración, ha influido en el contenido de tocoferol, en caso de los normales, tanto como en los genotipos mutantes, a través del incremento de $\alpha$ tocoferol. El contenido variaba de 81 a $97 \%$ en genotipo normal, de 33 a $50 \%$ en la mutación tph1, y de 0 a $6 \%$ en mutación tph2. Las mutaciones de tocoferol expresaban su fenotipo en diferentes partes de la planta. Todas las raíces, hipocotiles, hojas, polen y callos de la semilla, hipocotiles y hojas, tenían muta- 
ciones de tocoferol normales, tph1, tph2 y dobles, dependiente del genotipo. La única excepción fue falta de expresión tph1 en el tejido verde de las hojas. En el experimento en el cual la variación entre las temperaturas diurna y nocturna durante el desarrollo de la semilla fue de $20 / 18$ a $30 / 26^{\circ} \mathrm{C}$, se produjo el incremento del contenido de $\alpha$-tocoferol 39 hasta $48 \%$ en la mutación tph1. El genotipo normal (alrededor de $97 \% \alpha$-tocoferol) tanto como la mutación tph2 (alrededor de $98 \%$ de $\gamma$-tocoferol) fueron constantes en esos dos regímenes temperaturales. El fondo genético fue el factor principal que influyó en la expresión de tph2 en girasol.

\title{
EXPRESSION DU GÈNE DE MUTATION DU TOCOPHÉROL CHEZ LE TOURNESOL
}

\author{
RÉSUMÉ
}

Cette étude avait pour objet les effets de l'origine génétique, de l'ontogenèse et de l'environnement sur les mutations du tocophérol dans le tournesol. Le contenu de $\alpha / \beta$ - tocophérol variait de $40 / 60$ à $60 / 40 \%$ dans les akènes de différentes sources pures contenant le gène tph1. Les lignées contenant le gène tph2 variaient largement dans le contenu de $\alpha / \gamma$ - tocophérol, de $0 /$ 100 à $80 / 20 \%$. Une mutation double a révélé une variabilité dans le contenu de $\alpha / \beta / \gamma / \delta$ - tocophérol dans différentes sources pures pour une expression maximale de 0/0/60/40 à une expression minimale de 40/25/25/10\%, ce qui est dû à l'expression incomplète du gène tph2. La maturation de l'akène de 10 à 38 jours après la floraison a eu un effet sur le contenu de tocophérol dans les génotypes normaux comme dans les génotypes mutants par l'augmentation du contenu de $\alpha$-tocophérol. Le contenu variait de 81 à $97 \%$ dans un génotype normal, de 33 à $50 \%$ dans la mutation tph1 et de 0 à $6 \%$ dans la mutation tph2. Les mutations de tocophérol exprimaient leur phénotype dans différentes parties de la plante. Toutes les racines, hypocotyles, feuilles, pollen et calus des akènes, les hypocotyles et les feuilles avaient un tph1, tph2 et des mutations doubles du tocophérol normaux selon le génotype. La seule exception était l'absence d'expression de tph 1 dans le tissu vert des feuilles. Les variations de $20 / 18$ à $30 / 26^{\circ} \mathrm{C}$ des températures nocturne et diurne au cours du développement des akènes pendant l'expérience ont révélé une augmentation de 39 à $48 \%$ du contenu de $\alpha$-tocophérol dans la mutation tph1. Le génotype normal (environ $97 \%$ de $\alpha$-tocophérol) ainsi que la mutation tph2 (environ $98 \%$ de $\gamma$-tocophérol) ont été constants sous les deux régimes de température. L'origine génétique est le principal facteur ayant eu un effet sur l'expression tph2 dans le tournesol.

Presented at:

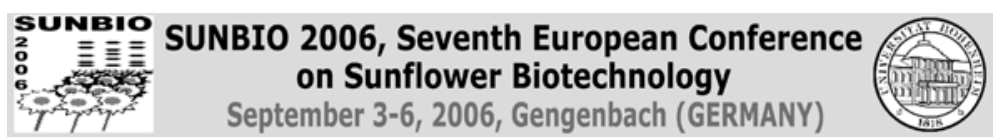

